\title{
SOYBEAN LECITHIN-BASED EXTENDER FOR CRYOPRESERVATION OF RAM
} SEMEN

\section{F. E. El-Azzaziand M. A. Yaseen}

Department of Animal Production, Faculty of Agriculture, Suez Canal University, Ismailia, Egypt

\section{SUMMARY}

This study was aimed to evaluate post thawed ram semen cryopreserved using extenders supplemented with soybean lecithin as a non-animal source of lipoprotein. Five mature Ossimi rams were used for semen collection. Good quality ejaculates (initial motility more than 70\%) were mixed together and treated as one pooled semen sample. A concentration of $2 \%$ soybean lecithin in Tris (hydroxy-methyl amino methane) extender was used and compared with the basic Tris-yolk extender. Pooled semen samples were diluted at the rate of 1:4 (semen to extender) using the two comparable extenders and were frozen in French plastic $0.5 \mathrm{ml}$ straws in liquid nitrogen. The results on post-thaw motility, recovery rates, hypo-osmotic swelling test, abnormal sperm, acrosome reacted spermatozoa and metabolic activity showed non-significant superiority of lecithin contained extender as compared to that fundamentally contained egg yolk.

It is concluded that replacing the fundamental egg yolk by soy bean lecithin in formulating ram semen extenders could be useful for better post-thaw quality of spermatozoa.

\section{Keywords: Soybean Lecithin, Cryopreservation, Semen, Ram}

\section{INTRODUCTION}

The application of sperm cryopreservation is important in assisting reproductive techniques, preservation of species, and studies concerning functional sperm activity and its interaction with the female gamete. In addition to the cryoprotectant glycerol, the basic components of diluents such as ionic or nonionic substances maintain osmolarity and provide buffering capacity. Also, this includes a source of lipoprotein or high molecular weight substance that prevent cold shock, such as egg yolk, milk, or soy lecithin. In addition, glucose or fructose as an energy source and other additives, such as enzymes and antibiotics (Vishwanath and Shannon 2000). The addition of components of animal origin (egg yolk, milk) to most commercial diluents used to freeze semen represents a potential risk of contamination with bacteria or mycoplasma. The two major membrane protectants commonly used in freezing media used for the long-term preservation of bull semen have been egg yolk (alone or in combination with milk) and glycerol, which preserves the integrity of membranes during freezing procedures. However, there has been increasing argument against incorporating egg yolk or milk to semen extender. This is due to the wide variability of their composition based on their various sources, in addition to the probable risk of contamination by bacteria or mycoplasma was also considered. The use of lecithin may prevent the contamination with bacteria and mycoplasma (Bousseau et al., 1998).

This glycerol-based product contains soybean lecithin as a replacement for egg yolk or egg yolk + milk, and thus has no products of animal origin. It has been shown that lecithin is the active component in protecting spermatozoa from cold shock. The efficacy of lecithin in embryo cryopreservation may be reduced by the negative effects of spontaneous lipid peroxidation, which occurs during aerobic incubation (Guyader-Joly et al., 1999).Although a new generation of semen diluents free of animal ingredients is available, egg yolk-contained extenders are still widely used for cryopreserving semen. Viviana et al. (2003) compared the effects of using different extenders on bovine sperm function in vitro and in vivo fertility. A soy lecithin extender and an egg yolk-containing extender were tested. They suggested that consistent with quality standards that should be required for cryoprotectant media and because of the superior quality of the egg yolk-free extender, a defined soybean lecithin containing diluents might be the better choice as a semen extender in the future. Generally, egg yolk is a common component of semen cryopreservation extenders for domestic animals. In goat, it was also shown to have a beneficial effect on sperm cryopreservation as a protector of the plasma membrane and acrosome against temperature related injury in association with other components (Purdy 2006). This cryoprotection is exerted during cooling, freezing and thawing (Aboagla and Terada 2004). However, the dilution of goat semen with diluents containing egg yolk or milk can have a detrimental effect on the quality of the sperm cells during cooling and cryopreservation (Sias et al., 2005).An alternative to egg yolk in extenders for ram semen could be soybean lecithin (Anel et al., 2006), which is present in several commercial extenders developed for bull semen. The efficacy of lecithin based extenders is still a matter of debate (Crespilho et al., 2012).The current study was aimed to compare the effect of lecithin-based extender (as a non-animal origin substance) with common commercial Egg-yolk-based extender on post-thawing ram sperm characteristics. 


\section{MATERIALS AND METHODS}

This study was carried out using five mature Ossimi rams aged about two years and weighed $45.40 \pm 2.11 \mathrm{Kg}$ in average. The rams were housed and managed at the experimental farm, Faculty of Agriculture, Suez Canal University, Ismailia, Egypt. The diets contained concentrated mixed ration and rice straw. The concentrated mixed ration was formulated and offered to meet the essential nutrient requirements of sheep according to NRC (2007). Rice straw was offered to the animals ad libitum and fresh water was available at all times.
Preparation of semen extenders:

As presented in Table (1), Tris-based extender was prepared at concentration of 297.58 mMTris, $96.32 \mathrm{mM}$ citric acid, $82.66 \mathrm{mM}$ fructose, $5 \%(\mathrm{v} / \mathrm{v})$ glycerol and freshly $20 \%(\mathrm{v} / \mathrm{v})$ egg yolk. Antibiotics were used at the rate of 500 IU Penicillin and $500 \mu \mathrm{g}$ Streptomycin per $\mathrm{ml}$. All of these ingredients were dissolved in $100 \mathrm{ml}$ distilled water (Fukui et al., 2008). The basic extender was split into two parts one supplemented with egg yolk and the other with soybean lecithin (LE030A-Bio Basic); L0 (zero lecithin and $20 \%$ egg yolk) and L1 (2\%w/v lecithin). The $\mathrm{pH}$ was adjusted to 6.8 using ADWA $\mathrm{pH}$ meter (AD1040, Romania).

Table1. Composition of Tris-yolkand Tris-lecithin-based extenders

\begin{tabular}{|c|c|c|}
\hline \multirow{2}{*}{$\begin{array}{l}\text { Ingredients } \\
\text { concentration }\end{array}$} & \multicolumn{2}{|c|}{ Extenders } \\
\hline & Egg Yolk Extender (L0) & Lecithin-Based Extender (L1) \\
\hline Tris Buffer (mM) & 297.58 & 297.58 \\
\hline Citric Acid (mM) & 96.32 & 96.32 \\
\hline Fructose (mM) & 82.66 & 82.66 \\
\hline Egg-Yolk (\%) & 20 & - \\
\hline Soy Lecithin ${ }^{*}(\%)$ & - & 2 \\
\hline Glycerol (\%) & 5 & 5 \\
\hline Antibiotics $^{* *}$ & $\checkmark$ & $\checkmark$ \\
\hline
\end{tabular}

\section{Semen collection and dilution:}

Two ejaculates per ram were collected using an artificial vagina. Only good quality ejaculates (initial motility more than $70 \%$ ) were mixed together and treated as one pooled semen sample. The semen samples were pooled to eliminate individual differences. After assessment of semen quality, each pooled semen sample was four-fold extended (V/V) with one of the above two extenders at room temperature.

\section{Cryopreservation:}

Extended semen was packaged into $0.50 \mathrm{ml}$ straws (I.V.M. L'Aigle, France). After equilibration period for one hour at $4^{\circ} \mathrm{C}$, straws were loaded onto straw holders, two to three centimeters, above the liquid nitrogen surface. They were exposed to liquid nitrogen $\left(\mathrm{LN}_{2}\right)$ vapor $\left(-125^{\circ} \mathrm{C}\right.$ to $\left.-130^{\circ} \mathrm{C}\right)$ for 10 min before being plunged into $\mathrm{LN}_{2}\left(-196^{\circ} \mathrm{C}\right)$ for storage. The frozen straws were thawed at $40^{\circ} \mathrm{C}$ for $30 \mathrm{sec}$ and the spermatozoa motility for each straw was evaluated (Fukui et al., 2008).

\section{Sperm motility and viability:}

Sperm motility was assessed by visual estimation (Roca et al., 2000). A drop of $10 \mu \mathrm{l}$ of thawed semen was delivered onto a clean glass slide and covered with a coverslip. The preparation was then examined under a warm phase contrast microscope at 600Xtotal magnification (Olympus, Japan). The percentages of sperm motility were estimated after viewing five microscopic fields.
Motility was recorded at the nearest $5 \%$ by a video screened conducted to Scalar USB Microscope (USB Shot, M3, Japan). Recovery rate was calculated by dividing post-thawing motility by initial sperm motility.

\section{Hypo-Osmotic Swelling Test:}

Sperm membrane integrity was assessed by observing the response of sperm cell to hypotonic media. The hypo-osmotic solution $(150 \mathrm{mOsm} / \mathrm{L})$ was prepared by dissolving $7.35 \mathrm{~g}$ sodium citrate $\left(\mathrm{Na}_{3} \mathrm{C}_{6} \mathrm{H}_{5} \mathrm{O}_{7} .2 \mathrm{H}_{2} \mathrm{O}\right)$ and $13.51 \mathrm{~g}$ fructose in $1000 \mathrm{~mL}$ of distilled water (Jeyendran et al., 1984). The solution was stored at $4^{\circ} \mathrm{C}$ till used. A volume of $10 \mu \mathrm{L}$ frozenthawed semen was gently mixed in each of the $2 \mathrm{~mL}$ hypo-osmotic solution and incubated at $37^{\circ} \mathrm{C}$ for one hour. Numbers of swollen sperm was observed every 15 minutes; a drop of incubated suspension was placed on a glass slide, covered with coverslip and examined under a microscope at $600 \mathrm{X}$ magnification. At least 100 sperm cells on each slide were randomly counted.

\section{Chlortetracycline test:}

The assay was carried out as described by Ward and Storey, 1984 and Lee et al. (1987). The chlorotetracycline (CTC) stock solution $(500 \mu \mathrm{M})$ was made by dissolving CTC-HCl (Bio-Basic, Canada Inc.) in a buffer containing 20 mMTris-acid, $130 \mathrm{mM} \mathrm{NaCl}, 5 \mathrm{mM}$ DL-cysteine (Acros organic, New Jersey, USA), pH 7.80, stored in a light-shielded container at $4^{\circ} \mathrm{C}$. Working solution of CTC was freshly made up. A $5 \mu \mathrm{L}$ aliquot of semen suspension 
was placed on a slide at $37^{\circ} \mathrm{C} ; 5 \mu \mathrm{L}$ of $\mathrm{CTC}$ stock solution was rapidly added, followed within 10sby $0.5 \mu \mathrm{L}$ of $12.5 \%$ glutaraldehyde in $1 \mathrm{M}$ Tris-base buffer, $\mathrm{pH}$ 7.8. A total of 100 spermatozoa were scored for each determination of the percentage of the acrosome-reacted spermatozoa in each sample. For evaluation of the CTC patterns, the samples were observed within 24 hours under a microscope equipped with phase contrast and epifluorescence optics; cells were then observed under blue-violet illumination (excitation at 400-440 $\mathrm{nm}$ and emission at $470 \mathrm{~nm}$ ). At least 100 spermatozoa per slide were classified according to one of three CTC staining patterns as described by Lee et al. (1987), Fraser et al. (1995) and Gillan et al. (1997). Acrosome-reacted spermatozoa show lack of (dull) fluorescence over the head, while the acrosome intact spermatozoa have been shown uniform head fluorescence or fluorescence only along the acrosome (Figure 1).
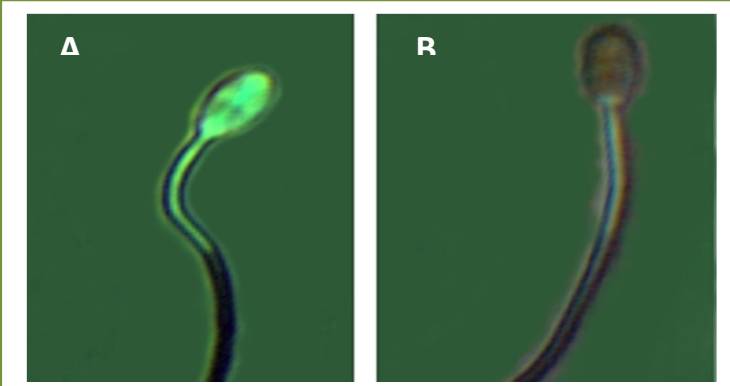

Figure 1: Fluorescent pattern of spermatozoa stained with chlortetracycline staining. A: intact acrosome sperm and B: acrosome reacted sperm.

Sperm Cell Concentration was assessed based on calibrated spectrophotometrically. Initial and post thawing fructose concentration was measured by colorimetric method as described by Foreman et al. (1973)

\section{Statistical analysis}

Data were statistically analyzed using Descriptive Analysis and General Linear Model (GLM), Procedure of SAS Software (SAS, 2004). One way analysis of variance was carried out for all post-thawed semen quality traits. According to Steel and Torrie (1984), means were compared using Duncan's multiple range test when the analysis of variance showed statistical differences. Differences were considered statistically significant at $P \leq 0.05$ level.

\section{RESULTS AND DISCUSSION}

The use of animal-protein free extenders for semen cryopreservation was found to overcome problems associated with traditional egg yolk based extenders, including contamination and variability of composition (de Paz et al., 2010). In the current study, the protective effects of soybean lecithin-based extender ( $2 \%)$ on post-thawing sperm parameters were studied and compared with those of Egg yolk-based extender.
Results in Table (2) show that lecithin-based extender does not have any bad impact on post-thawed semen. The use of non-animal origin lecithin extenders had good benefits on post thaw characteristics of ram semen. However, the differences were not significant between the soybean lecithin-based extender and traditional Egg-yolk extender. The percentages of progressive motility were $51.46 \%$ and $51.83 \%$ in Eggyolk and lecithin-based extenders, respectively. The recovery rates were $60.55 \%$ using Egg-yolk extender and $60.98 \%$ using Lecithin extender. Our results are in agreement with Akhter et al. (2012) and Khalifa and Abdel-Hafez (2014). They also reported no significant effect between Soy Lecithin and Egg-yolk-based extenders on post-thawing progressive motility, viability and acrosomal abnormality. In addition, previous studies suggested that the addition of soylecithin to semen extender improved post-thawing sperm motility, viability, acrosome integrity and sperm membrane structure in human (Reed et al., 2009), stallion (Papa et al., 2011), bull (Singh et al., 2013) and rams (Khalifa and Abdel-Hafez, 2013). Percentage of fructose utilization was slightly better $(5.26 \%)$ in post-thawed semen samples diluted in Lecithin-based extenders comparing with Egg-Yolk extender (5.22\%), but the differences were not significant. In addition, fructolysis index, which is the ideal means to determine the activity and metabolism of spermatozoa after freezing and thawing, was better in Lecithin extender than in Egg-Yolk extender, but the differences were not significant. Quite improvement in metabolic rates was obtained in lecithin treatment, where post-thawing fructolysis index was 1.50 and $1.48 \mathrm{mg}$ fructose $/ 10^{6} / \mathrm{hr}$ for Lecithin and Egg-Yolk extender, respectively.

Data in table (2) illustrate that change in acrosome integrity show that the percentages of spermatozoa with intact acrosome were 71.25 using Lecithin extender and 68.98\% using Egg-Yolk extender. Therefore, percentage of acrosome reacted spermatozoa were 28.75 and $31.02 \%$ in Lecithin and Egg-yolk extender, respectively. Abnormal spermatozoa were 18.17 and $19.96 \%$ for Lecithinbased and Egg-Yolk extender, respectively. From the present results, it could be observed that using nonanimal origin of phosphatidyl choline instead of yolk phosphatidyle choline had not any adverse effects on abnormalities. Previous studies reported higher sperm total motility and plasma and acrosomal integrity for semen cryopreserved using lecithin based commercial extenders, developed for use with plantderived compounds (Amirat et al., 2005).The composition of semen extenders strongly influences sperm survival (Chaveiro et al., 2006), therefore the better results found for soybean lecithin extenders could be related solely to the cryoprotectant effect of the lecithin. These results may be due to the lower viscosity found in lecithin-based extenders when compared to the Tris-egg yolk-sodium citrate (Zhang et al., 2009). In addition, de-Paz et al. (2010) found that the semen extender prepared using a concentration of soybean up to $3.5 \%$ showed a higher 
content of phospholipids which was able to preserve the sperm motility and viability. The lipid particles in egg yolk based extenders could also cause a deleterious effect on progressive motility, acting as a physical barrier for spermatozoa, influencing natural sperm trajectory (Crespilho et al., 2012).Otherwise, the lowest sperm survival in egg yolk contained extender may be related to microbial or sanitary aspects (Hu et al., 2010). The mammalian sperm contain a high concentration of polyunsaturated fatty acids in the plasma membrane which make sperm susceptible to lipid peroxidation when egg yolk is supplemented to extender. The lipid peroxidation leads to deterioration of sperm functions through oxidative stress and the production of components such as malondialdehyde that is one of the most prevalent by-products of lipid peroxidation. Reactive oxygen species (ROS) in semen decreases energy metabolism, progressive motility, viability rate and DNA integrity in sperm. Lecithin of plant origin (soy bean) could successfully substitute egg yolk in field trials for livestock semen (Khalifa and Abdel-Hafez, 2014).These results are in agreement with the findings by Fukui et al. (2008), who reported that lecithin may have a protective role for spermatozoan during freezing. This could be attributed to low viscosity, improvement of the kinematics of sperm membrane and rearrangements of phospholipid of the sperm cells membrane. Moreover, the influential antioxidant compounds in soy lecithin as glutathione may protect the sperm viability via scavenging the lipid peroxidation and prevention of malondialdehyde formation during cooling or freezing process (Salmani et al., 2013). Soybean lecithin extender recovered motility, plasma membrane acrosome integrity, apoptosis status and mitochondrial activity after thawing of ram spermatozoa (Del Valle et al., 2012). Also, Crespilho et al. (2012) reported higher sperm motility and acrosomal integrity for semen cryopreserved using lecithin based commercial extenders for freezing bovine semen.

Table 2. Means \pm SE for post-thawing characteristics and metabolic activity of ram semen extended in two different extenders

\begin{tabular}{lccccc}
\hline \multicolumn{1}{c}{ Items } & \multicolumn{2}{c}{ Extenders } & \multicolumn{1}{c}{ P. } \\
\cline { 2 - 6 } & $\begin{array}{c}\text { Egg Yolk } \\
\text { Extender (L0) }\end{array}$ & \multicolumn{2}{c}{ Lecithin-based Extender (L1) } \\
\hline Post-Thaw Motility (\%) & $51.46 \pm 1.73$ & $(41)$ & $51.83 \pm 1.33$ & $(42)$ & 0.969 \\
Recovery Rate (\%) & $60.55 \pm 2.04$ & $(41)$ & $60.98 \pm 1.56$ & $(42)$ & 0.969 \\
HOST *\%) & $47.73 \pm 1.33$ & $(29)$ & $48.03 \pm 1.14$ & $(30)$ & 0.866 \\
Fructolysis Index (mg) & $1.48 \pm 0.27$ & $(20)$ & $1.50 \pm 0.27$ & $(21)$ & 0.949 \\
Fructose Utilization (\%) & $5.22 \pm 0.90$ & $(19)$ & $5.26 \pm 0.88$ & $(19)$ & 0.980 \\
Intact Acrosome (\%) & $68.98 \pm 1.48$ & $(20)$ & $71.25 \pm 1.55$ & $(20)$ & 0.315 \\
Acrosome Reacted Sperm (\%) & $31.02 \pm 1.48$ & $(20)$ & $28.75 \pm 1.55$ & $(20)$ & 0.315 \\
Abnormalities (\%) & $19.96 \pm 1.55$ & $(20)$ & $18.17 \pm 0.85$ & $(20)$ & 0.284 \\
\hline
\end{tabular}

"HOST: Hypo-osmotic swelling test

\section{CONCLUSION}

The results of the current study indicate that soy lecithin extenders could be used to preserve sperm motility, viability and plasma membrane integrity during freezing-thawing processes. Hence, the nonanimal origin cryoprotectants could be recommended for use in formulating ram semen extenders. This could also be useful for minimizing micro-organisms contamination of ram semen, resulting in better AI results in this animal.

\section{ACKNOWLEDGMENT}

The financial support from the Faculty of Agriculture, Suez Canal University is gratefully acknowledged.

\section{REFRENCES}

Aboagla, E.M.E. and T.Terada, 2004. Effects of egg yolk during the freezing step of cryopreservation on the viability of goat spermatozoa. Theriogenology, 62:1160-1172.

Akhter, S., M.S. Ansari, S.M. Andrabi, B.A. Rakha, N. Ullah and M. Khalid, 2012. Soya-lecithin in extender improves the freez ability and fertility of buffalo (Bubalus bubalis) bull spermatozoa. Reprod. Domest. Anim., 47:815-819.

Amirat, L., M. Anton, D. Tainturier, G. Chatagnon, I. Battut and J.L. Courtens, 2005. Modifications of bull spermatozoa induced by three extenders: Biociphos, low density lipoprotein and Triladyl, before, during and after freezing and thawing. Reproduction, 129:535- 543.

Anel, L., M. Álvarez, F. Martínez-Pastor, V. GarcíaMacías, E. Anel and P. Paz, 2006. Improvement 
strategies in ovine artificial insemination.Reprod. Dom. Anim., 41: 30-42

Bousseau, S., J.P. Brillard, M. Guienne, B. Guerin, A. Camus and M. Lechat, 1998.Comparison of Bacteriological qualities of various egg yolk sources and the in vitro and in vivo fertilizing potential of Bovine semen frozen in egg yolk or lecithin-based diluents. Theriogenology, 50: 699-706.

Chaveiro, A., L. Machado, A. Frijters, B. Engel and H. Woelders, 2006. Improvement of parameters of freezing protocol for bull sperm using two osmotic supports. Theriogenology, 65: 18751890.

Crespilho A.M., M.F. Sa'Filho, J.A. Dell'Aqua Jr., M. Nichi, G.A. Monteiro, B.R. Avanzi, A. Martins and F.O. Papa, 2012. Comparison of in vitro and in vivo fertilizing potential of bovine semen frozen in egg yolk or new lecithin based extenders. Livestock Sci., 149:1-6.

de Paz P., M.C. Esteso, M. Alvarez, M. Mata, C.A. Chamorro and L. Anel, 2010. Development of extender based on soybean lecithin for its application in liquid ram semen. Theriogenology, 74: 663-671.

Del Valle I., A. Gomez-Duran, W.V. Holt, T. MuinoBlanco, and J.A. Cebrian-PE Rez, 2012. Soy Lecithin Interferes With Mitochondrial Function in Frozen-Thawed Ram Spermatozoa. J. Androl., 33: 717-725.

Foreman, D., L. Gaylor, E. Evans and C. Trella, 1973. A modification of the Roe procedure for determination of fructose in tissues with increased specificity. Analytical Biochemistry, 56:584-590.

Fraser, L.R., L.R. Abeydeera, and K. Niwa, 1995. $\mathrm{Ca}^{2+}$-regulating mechanisms that modulate bull sperm capacitation and acrosomal exocytosis as determined by chlortetracycline analysis. Mol. Reprod. Dev., 40: 233-241.

Fukui, Y., H. Kohno, T. Togari, M. Hiwasa, and K. Okabe, 2008. Fertility after artificial insemination using a soybean based semenextender (Andromed) in sheep. J. Reprod. Dev., 54: 286-289.

Gillan, L., G. Evans and W.M.C. Maxwell, 1997. The capacitation status and fertility of fresh and frozen-thawed ram spermatozoa. Reprod. Fert. Dev., 9: 481-487.

Guyader-Joly C., S. Ponchon, M. Durand, Y. Heyman, J.P. Renard and Y. Menezo, 1999. Effect of lecithin on in vitro and in vivo survival of in vitro produced bovine blastocysts after cryopreservation. Theriogenology, 52: 1193-1202.

Hu J.H., Q.W. Li, L.S. Zan, Z.L. Jiang, J.H. An, L.Q. Wang and Y.H. Jia, 2010. The cryoprotective effect of low density lipoproteins in extenders on bull spermatozoa following freezing-thawing. Anim. Reprod. Sci., 117: 11-17.

Jeyendran R.S., H.H. Vander-Ven, M. Perez-Pelaez, B.G. Crabo and L.J.D. Zanevld, 1984. Development of an assay to assess the functional integrity of the human sperm membrane and its relationship to other semen characters. J. Repord. Fertil., 70: 219-228.

Khalifa, E.I. and M.A.M. Abdel-Hafez, 2013. Evaluation of different levels of soybean lecithin as an alternative to egg yolk for cryopreservation of goat and ram spermatozoa. Journal of Animal and Poultry Sciences, 13: 1-6.

Khalifa, E.I. and M.A.M. Abdel-Hafez, 2014. Effect of soybean lecithin-based semen extender on freezability and fertility of Rahmani ram spermatozoa. Egyptian Journal of Sheep and Goat Sciences, 9: 59- 66

Lee M.A., G.S. Trucco, K.B. Bechtol, et al., 1987. Capacitation and acrosome reactions in human spermatozoa monitored by a chlortetracycline fluorescence assay. Fertil. Steril., 48: 649-658.

National Research Council, 2007. Nutrient requirements of small ruminants ( $1^{\text {st }}$ edition). NRC, National Academy Press: Washington, DC, USA.

Papa F.O., G.B. Felicio, C.M. Melo-õn, M.A. Alvarenga, B.D. Vita, C. Trinque, J.N.P. Puolifilho and Jr. J.A. Dell'Aqua, 2011. Replacing egg yolk with soybean lecithin in the cryopreservation of stallion semen. Anim. Reprod. Sci., 129: 73-77.

Purdy P.H., 2006. A review on goat sperm cryopreservation. Small Ruminant Research, 63:215-225.

Reed M.L., P.C. Ezeh, A. Hamic, D.J. Thompson and C.L. Caperton, 2009. Soy lecithin replaces egg yolk for cryopreservation of human sperm without adversely affecting post thaw motility, morphology, sperm DNA integrity, or sperm binding to hyaluronate. Fertil. Steril., 92:1787-1790.

Roca J., S. Martínez, J.M. Vázquez, X. Lucas, I. Parrilla and E.A. Martínez, 2000. Viability and fertility of rabbit spermatozoa diluted in Tris-

buffer extenders and stored at $15^{\circ} \mathrm{C}$. Anim. Reprod. Sci., 64: 103-112.

Salmani H., M.M. Nabi, H. Vaseghi-Dodaran, M.B. Rahman, A. Mohammadi-Sangcheshmeh, M. Shakeri, A. Towhidi, A. Z. Shahneh and M. Zhandi, 2013. Effect of glutathione in soybean lecithin-basedsemen extender on goat semen quality after freeze-thawing. Small Ruminant Research, 112: 123-127.

SAS. 2004. SAS/STAT ${ }^{\circledR} 9.1$ User's Guide. SAS Inst. Inc., Cary NC, USA

Sias B., F. Ferrato, M.T. Pellicer-Rubio,Y. Forgerit, P. Guillout, B. Leboeuf and F. Carriere, 2005. Cloning and seasonal secretion of the pancreatic lipase-related protein2 present in goat seminal plasma. Molecular and Cell Biology of Lipids, 1686:169-180.

Singh V.K., A.K. Singh, R. Kumar and S.K. Atreja, 2013. Development of soya milk extender for semen cryopreservation of Karan Fries (crossbreed cattle). Cryoletters, 34: 52-61.

Steel, R.G.D. and J.H. Torrie, 1984.Principles and Procedures of Statistics. McGraw Hill Book Co. Inc., New York. pp: 336-6. 
Vishwanath R. and P. Shannon, 2000.Storage of bovine semen in liquid and frozen state.Anim. Reprod. Sci., 62: 23-53.

Viviana A.A., K.D. Hinsch, K.S. Mueller-Schloesser, F. Bogner, S. Mueller-Schloesser and E. Hinsch 2003. In vitro and in vivo comparison of egg yolkbased and soybean lecithin-based extenders for cryopreservation of bovine semen. Theriogenology, 60: 269-279
Ward C.R. and B.T. Storey, 1984.Determination of the time course of capacitation in mouse spermatozoa using a chlortetracycline fluorescence assay. Dev. Biol., 104: 287-296.

Zhang S.S., J.H. Hu, Q.W. Li, Z.L. Jiangand and Z. Xiaoying, 2009. The croyoprotective effects of soybean lecithin on boar spermatozoa quality. African Journal of Biotechnology, 8: 6476-6480.

استخدام مخفف ليسيثين فول الصويا في حفظ السائل المنوي للأغنام الأوسيمي بالتجميد

$$
\text { فخري العزازي، محمد أحمد يس الإنتاج الحيو/ني والثروة السكبة، كلية الزراعة، جامعة قناة السوبي، الاسماعيلية،صر }
$$

أجريت هذه الدراسة بهدف تقييم جودة السائل المنوي بالإضافة إلى معدلات الميتابوليزم بعد التجميد والاسالة وذلك بعد إدراج

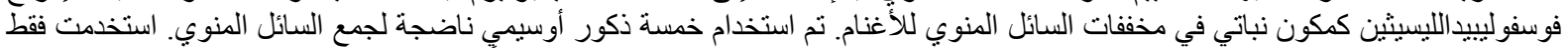

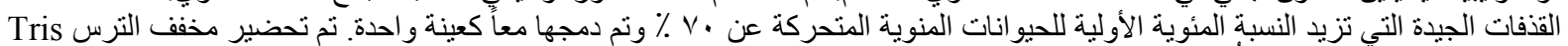

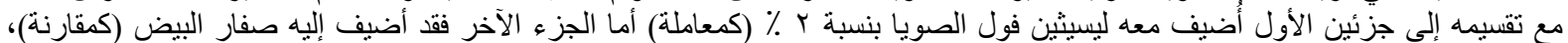

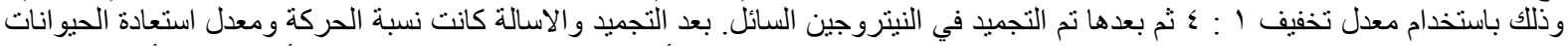

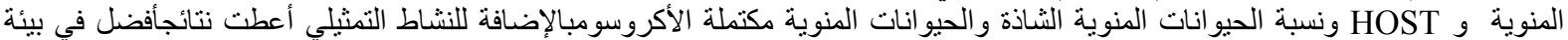

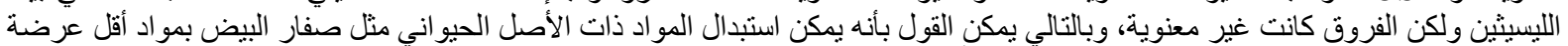

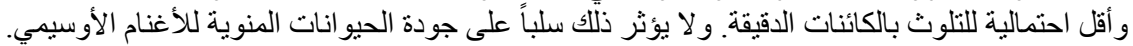

